DOI 10.18551/rjoas.2019-06.03

\title{
POTENTIAL AND PERCEPTION OF COMMUNITY IN MANAGING LATUPPA AGRO-ECOTOURISM AREA IN PALOPPO
}

\author{
Rahmat, Doctoral Student \\ Environmental Science Program, Postgraduate School, University of Brawijaya, Indonesia
}

Hakim A.

Department of Public Administrative Science, Faculty of Administrative Science, University of Brawijaya, Indonesia

Riniwati H.

Department of Fishery Social Economics, Faculty of Fisheries and Marine Science, University of Brawijaya, Indonesia

Yasin $\mathrm{H}$.

Faculty of Fisheries and Marine, Indonesian Islamic University, Indonesia

*E-mail: udien.udan@gmail.com

\begin{abstract}
Latuppa Area has great natural resources potential to develop. There has been environmental damage happening lately. Agro-ecotourism concept can be used to reduce the damage. Latuppa Area is located in Palopo City and it belongs to protected forest and recharge area at an elevation of 200 meters above sea level (masl). Besides that, this area is also a water resource for Palopo people. The development of Latuppa potential should be well managed by prioritizing environmental education and local community empowerment. In order to achieve a well management of area, data collection about the perception of the local community, visitors and stakeholders is needed. This study aims to describe potential and support of Latuppa Agro-ecotourism and to know the perception of the local community and the practitioners in managing Latuppa agro-ecotourism area in Palopo City.
\end{abstract}

\section{KEY WORDS}

Agro-ecotourism, Latuppa potential, community's perception, Palopo City.

Palopo is a city which is located in South Sulawesi Province. Previously, Palopo was an administrative city since 1986 and a part of Luwu District which transformed into city region in 2002 based on the Act No. 11, 2002 in 10 April 2002. Geographically, Palopo is

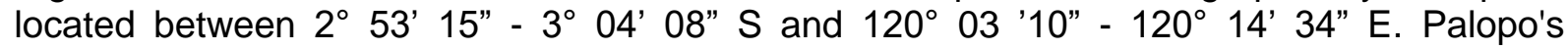
administrational width is about $247,52 \mathrm{Km} 2$ or the same with $0,39 \%$ of the South Sulawesi Province's width. Palopo, with its location in the coastal area, is mostly lowlands which is about $62,85 \%$ of the total width of Palopo, showing that the region is located at an elevation of $0-500$ masl. About $24,76 \%$ of the region is located at an elevation of $501-1000$ masl and the rest which is about $12,39 \%$ is located at an elevation of 1000 masl.

The natural resource in Palopo has a very great potential to develop. It covers the forests which has many benefits for human life. Affandi and Patana (2002) stated that based on the shape, forests can be classified into two: tangible benefits and intangible benefits. The tangible benefits are the woods/logs, forest products and many others. Intangible benefits are the water regulation, recreation, education, environmental comfort and etc.

Generally, in tourism development, there is a term of sustainable tourism. Sustainable tourism is considered as a step to manage resources socially and economically and can be done by preserving the cultural integrity, basic ecology process, biological diversity, and other life support elements, by optimizing the potential of a 
tourism area. One of the efforts of optimum local resources utilization is by developing tourism using the concept of ecotourism (Satria, 2009).

The potential of tourism, lately, is mostly related and used to solve the problems which have been facing by the world such as the natural resources loss and other environmental issues. One of the efforts of optimum local resources utilization is by developing tourism using the concept of ecotourism (Satria, 2009). Tourism cannot be separated with conservational efforts, local economy empowerment and support on higher respect of cultural differences. This underlies the difference between ecotourism concept and the preexisting conventional tourism model.

Ecotourism is a nature-based tourism trip which depends very much on the nature, environment, ecosystem and its local wisdom that should be preserved (Yoeti, 2008). Indonesian Tourism and Culture Department (2009) stated that ecotourism is aimed at enjoying and learning the nature, history and culture at a region which the tourism pattern helps its local community's economy and supports the nature preservation.

The management plan of an area in terms of agro-ecotourism needs accurate and representative data. The data have to be based on the situation and recent condition. One of the basic data which is needed to collect is the community's perception. A community's perception is a perspective which directs community's respect in dealing with surrounding phenomena. The community has to be involved and considered regarding with their perception in managing the environment. That is why, perception is considered as a basic element which is needed to plan and be known before planning the activities involving the local community. This study aims to describe potential and support of Latuppa Agroecotourism and to know the perception of the local community and the practitioners in managing Latuppa agro-ecotourism area in Palopo City.

\section{METHODS OF RESEARCH}

The design of the study used in the study of community's and practitioners' potential, support and perception in managing a sustainable agro-ecotourism in Palopo, South Sulawesi is a qualitative method. In the study, a qualitative descriptive analysis was used to know the perception of the practitioners of Latuppa agro-ecotourism in Palopo. the technique of data collection covers the observation, interview with the visitors, practitioners and tourism managers and the stakeholder.

The technique of data collection was:

- Observation, the data collection was done by doing a direct observation on the study respondents;

- The questionnaires, the data collection method was performed by giving some structured written questions to the respondents about their answers on various studied variables in the study;

- Interview, the data collection was to conduct a depth questions and answers with the respondents to obtain the more accurate and complete data regarding with further explanation of the questionnaires.

\section{RESULTS AND DISCUSSION}

The Potential of Latuppa Agro-ecotourism in Palopo. Based on Pedoman Analisis Daerah Operasi Objek and Daya Tarik Wisata Alam (the Object Operation Area Analysis Guide and the Natural Tourist Attraction) of General Directorate in 2003, the function of the criteria and the indicators is as the base in developing the Natural Tourist Attraction. The aim of developing the criteria was to determine the priority scale of natural tourist attraction and intensifying its utilization and construction. Latuppa Region has a great natural resources potential to develop. The potential is developed with the concept of agro-ecotourism. Latuppa area which is located in Palopo City at an elevation of 200 masl is a protected forest and a recharge area. This area is also a water resource for Perusahaan Daerah Air Minum (the Local Drinking Water Company) in Palopo. Latuppa has objects or potentials which are 
developed to be the tourist attraction. The development of Latuppa's potential is managed by prioritizing the environmental education tourism and also local community empowerment, so that the development uses the system of agro-ecotourism.

The Potential Attraction of the Area. The potentials of the area which have been the tourism attraction for both Palopo community and the tourist in Latuppa are:

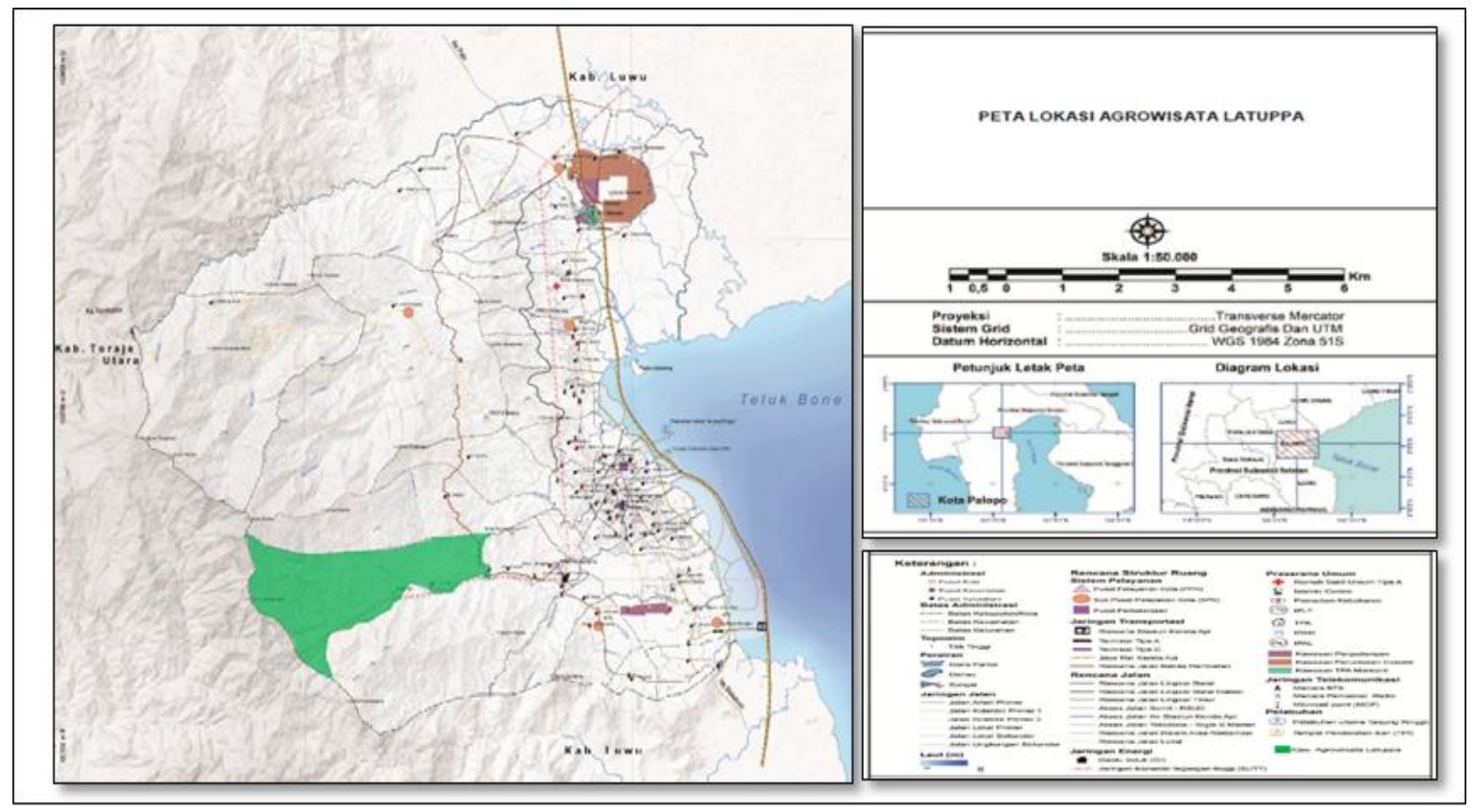

Figure 1 - The Map of the Agro-ecotourism Location of Latuppa

Latuppa produces abundant agricultural products. The agricultural results are bought as agricultural hand-gifts by the visitors or the public society. The type of this tourism object provides plantation products such are durian, Peta langsat, patikala, dangen and sagu making process. These plants are special plants in Luwu which have great potential to develop. The local community empowerment can be done to raise the economic prosperity of Palopo local community.

Peta indigenous Area also has potential in culinary, both food and drinks, to develop. The types of food are Sokko Sikapa, Peong (Lemmang), Duku fruit, Peta langsat, and Trigona honey. Trigona honey is special honey of the indigenous community which is starting to extinct and is difficult to find. In order to overcome this issue, a cooperative work between trigona honey farmers and the local government in order to support honey management or other local food to attract visitors in Latuppa is needed.

The indigenous area of Peta also provides the products for the visitors. The types of crafts are alas piring ijuk (the plate coaster made of coconut fiber) known as Lakka, Baka (basket made of bamboo), banga (plate made of maja fruit). Based on the potential of the crafts in indigenous area of Peta, workshop and empowerment for those who have skill in making the crafts can be conducted in the community. This, of course, needs support from the government.

The recreational parks in local area are Tandung Waterfall and Salo Kassi Tandung Waterfall. Until nowadays, the community has not understood the management and development of this tourism location. Thus, they tend to do the farming and agriculture. However, the area has not been managed maximally and that makes the area unpopular to the public. The potential possessed by the area is very great. Therefore, cooperation between the community and the government or related stakeholders is needed, so that the management and the development of the area can be improved.

This area also has Peta Indigenous Village which can be made into cultural and history tourism object. The indigenous people know cultural history of Peta, its law and regulation 
and Peta indigenous cultural group. Traditional houses or the heritage of Peta should be preserved, so that the history and the culture do not distort and get extinct. It is also hoped that the young generation comprehend and preserve the cultural heritage.

Accessibility is defined as how easy people access or get to the objects, service, or environment. The access can be in terms of the constructions, environment, and other public facilities. Latuppa and Palopo is quite close with distance of $\pm 10 \mathrm{Km}$ and good infrastructure. To get to Latuppa, cars or motorbikes can be used. Latuppa is not very far from Airport of Port. The access or trip from Airport Bua to Latuppa takes $30-40$ minutes or $23 \mathrm{~km}$. The distance of Tanjung Ringgit Port and Latuppa is about $13 \mathrm{~km}$. This easy-to-get distance to Latuppa can be attraction to public to come and visit Latuppa agro-ecotourism.

The availability of accommodation in tourism area is an important factor for the visitors, so that they can stay in the area. MacKinnon et. al. (Ginting et. al., 2015) stated that accommodation is one of the factors that attracts the visitors to come to a place. Latuppa agro-ecotourism area also provides hotel or resorts for the visitors where they can stay in Palopo because Latuppa is not far from Palopo.

There are interesting tourism objects for tourist in Latuppa. Infrastructure and facilities are important for Latuppa Agro-ecotourism development such as providing convenient facilities for the visitors. The provided facilities are:

- The main facilities in the development of Latuppa agro-ecotourism are: tourism-aware group which is active in developing and managing Latuppa waterfall tourism object;

- The public facilities are: security post, bathrooms, changing rooms, garbage bins, parking lots, information and regulation boards and gazebos;

- The supporting facilities are hotels, warung (small shops), and kiosks.

The Community's Perception towards the Management of Latuppa Agro-Ecotourism Area in Palopo. Tourism in Indonesia nowadays directs mostly on natural tourism which includes natural and marine tourism. This means that the tourism object that are mostly visited are the natural objects which are many in Indonesia. Therefore, natural tourism covers environment condition. Thus, the beauty, originality, comfort, and cleanliness of the tourism objects become the important indicators for further development of a tourism object. Palopo has abundant natural and cultural resource potential to develop such as: Langkanae Traditional House, Batara Guru Museum, Sampoddo' Hill, Labombo Beach, Songka Beach and Latuppa tourism Village (Senna, 2014). One of the aspects which supports the natural resource potential is the close access to get to Latuppa from Palopo with very good infrastructure. This easy-to-get distance to Latuppa can be attraction to public to come and visit Latuppa agro-ecotourism.

The perception of the visitor is the visitors' view or judgment on something. A tourism object should improve its quality to get better to get a positive perception. Perception in tourism is opinion of the visitors to understand a tourist destination. Tourists' perception is one of important things in developing a tourist destination. Something liked, demanded, or desired by the visitors of a tourist destination is important in tourism object marketing (Warpani, 2007).

Based on the interview about perception of tourism area attraction in Palopo City, about $53,3 \%$ of the people think that the place, mostly the natural view, is attractive. in terms of the plants, $53,3 \%$ of them said attractive, $40 \%$ of them said fairly attractive. In terms of the animals, they said that it was less attractive. This because there are not many animals in the area. In category of waterfall, $73,33 \%$ of the people said it was very attractive. it is because the potential owned by the area is very good where it is still natural and beautiful. There is also an attractive footpath to walk on.

Based on the interview on the visitors' perception on the accessibility, it is revealed that they think that it is supportive. It can be seen from the footpath at Latuppa Waterfall that gives easy access for the visitors to get to the attraction spot. The condition of tourist attraction entrance with the highest score in supportive category is 53,3\%. The access from Palopo to Latuppa is quite close with distance of $\pm 10 \mathrm{Km}$ with very good infrastructure and the availability of the road signs to Latuppa area. This is in category of fair with the percentage of $40 \%$. However, the availability of the transportation facility to the tourist area is 
in category of less supportive with the percentage of $53,3 \%$. This is because the only transportation to get to Latuppa area is ojek (taxibike). Other public transportations have not reached Latuppa area.

Table 1 - The Perception about Tourist environment attraction

\begin{tabular}{|c|l|c|c|c|c|c|c|}
\hline No & \multicolumn{1}{|c|}{ Tourist attraction } & $\begin{array}{c}\text { Very } \\
\text { attractive (\%) }\end{array}$ & $\begin{array}{c}\text { Attractive } \\
(\%)\end{array}$ & $\begin{array}{c}\text { Fairly } \\
\text { attractive (\%) }\end{array}$ & $\begin{array}{c}\text { Less } \\
\text { attractive (\%) }\end{array}$ & $\begin{array}{c}\text { Not attractive } \\
(\%)\end{array}$ & $\begin{array}{c}\text { Jlh } \\
(\%)\end{array}$ \\
\hline 1 & Natural scenery & 53,33 & 33,3 & 13,33 & - & - & 100 \\
\hline 2 & Plants/flora & 6,667 & 53,3 & 40 & - & - & 100 \\
\hline 3 & Animals/fauna & - & 40 & 53,33 & 6,667 & - & 100 \\
\hline 4 & Rivers/waterfall & 73,33 & 13,3 & 13,33 & - & - & 100 \\
\hline 5 & $\begin{array}{l}\text { Water attraction (swimming } \\
\text { pool, water park) }\end{array}$ & 20 & 40 & 40 & - & - & 100 \\
\hline 6 & Footpath/bridges & 33,33 & 53,3 & 13,33 & - & - & 100 \\
\hline
\end{tabular}

Source: The Result of the study in 2018.

Table 2 - The Perception on the access to get to tourist attraction

\begin{tabular}{|c|c|c|c|c|c|c|c|}
\hline \multirow[b]{2}{*}{ No } & \multirow[b]{2}{*}{ Infrastructure/accessibility } & \multicolumn{5}{|c|}{ the Condition of accessibility } & \multirow[b]{2}{*}{$\begin{array}{l}\mathrm{Jlh} \\
(\%)\end{array}$} \\
\hline & & $\begin{array}{c}\text { Very } \\
\text { supportive }\end{array}$ & Supportive & Fair & $\begin{array}{c}\text { Less supportive } \\
(\%)\end{array}$ & $\begin{array}{c}\text { Not } \\
\text { supportive }\end{array}$ & \\
\hline 1 & $\begin{array}{l}\text { The Road Entrance of Tourist } \\
\text { location }\end{array}$ & 26,67 & 53,3 & 20 & - & - & 100 \\
\hline 2 & $\begin{array}{l}\text { The availability of the } \\
\text { transportation }\end{array}$ & 6,667 & 13,3 & 26,67 & 53,33 & - & 100 \\
\hline 3 & The road signs & 13,33 & 33,3 & 40 & 13,33 & - & 100 \\
\hline
\end{tabular}

Source: The Result of the study in 2018.

The visitors' satisfaction and comfort in enjoying the scenery in Latupa tourism area are categorized as very satisfied with the highest percentage $46,4 \%$. This is based on the results of the interview with the visitors who think that the available facilities in Latuppa tourism area are already good, yet it needs to be improved and managed by the managers of the place. Latuppa tourism area still has a preserved nature with flora and fauna species diversity with the percentage of comfort of $46,6 \%$ categorized as fair. There is a tracking path or footpath along the riverbanks to to waterfall. The river is still clean. This makes the highest point which is in satisfied category with percentage of $60 \%$ and $66,6 \%$. This gives comfort to the visitors.

Table 3 - The level of tourists' comfort

\begin{tabular}{|c|c|c|c|c|c|c|c|}
\hline \multirow[b]{2}{*}{ No } & \multirow[b]{2}{*}{ Activities } & \multicolumn{5}{|c|}{ Infrastructure condition } & \\
\hline & & $\begin{array}{c}\text { Very } \\
\text { satisfied (\%) }\end{array}$ & $\begin{array}{c}\text { Satisfied } \\
(\%)\end{array}$ & $\begin{array}{c}\text { Fairly } \\
\text { satisfied (\%) }\end{array}$ & $\begin{array}{c}\text { Less } \\
\text { satisfied (\%) }\end{array}$ & $\begin{array}{c}\text { Not satisfied } \\
(\%)\end{array}$ & $\begin{array}{l}\text { Jlh } \\
(\%)\end{array}$ \\
\hline 1 & Enjoying the scenery & 46,67 & 40 & 13,33 & - & - & 100 \\
\hline 2 & Observing the animals and plants & - & 33,3 & 46,67 & 20 & - & 100 \\
\hline 3 & Walking down the footpath & 26,67 & 60 & 13,33 & - & - & 100 \\
\hline 4 & $\begin{array}{l}\text { Walking down and enjoying the } \\
\text { river/other water attraction }\end{array}$ & 33,33 & 66,7 & - & - & - & 100 \\
\hline
\end{tabular}

Source: The Result of the study in 2018.

\section{CONCLUSION}

There are various potentials obtained from the study, starting from the natural resource to good human resource. Surely, they need attention, the local government's roles to synergize with the local community in developing the agro-ecotourism in Latuppa to increase the numbers of visitors or tourists.

According to the community's perception, the management of agro-ecotourism in Latuppa area which covers the accessibility, facilities and infrastructure meets the demand. However, there are many of the society who demands the new tourist attraction to attract the tourists. The improvement of the tourists' area should consider the potential owned by the area for the sake of good management and better tourist attraction. 


\section{REFERENCES}

1. Affandi, O., and Patana, P. 2002. Perhitungan Nilai Ekonomi Pemanfaatan Hasil Hutan Non-marketable oleh Masyarakat Desa Sekitar Hutan Studi Kasus Cagar Alam Dolok Sibual-buali, Kecamatan Sipirok, Tapanuli Selatan). Laporan Penelitian. Program IImu Kehutanan - Universitas Sumatera Utara. Tidak diterbitkan.

2. Satria, D. 2009. "Strategi Pengembangan Ekowisata Berbasis Ekonomi Lokal dalam Rangka Program Pengentasan Kemiskinan di Wilayah Kabupaten Malang". Di Journal of Indonesian Applied Economics. Vol 3: 2087 - 2852

3. Yoeti, O. A. (2008). Perencanaan and Pengembangan Pariwisata. Jakarta: PT. Pradnya Pramita.

4. Departemen Kebudayaan and Pariwisata Indonesia. (2009). Prinsip and Kriteria Ekowisata Berbasis Masyarakat. Jakarta: Departemen Kebudayaan and Pariwisata Indonesia RI.

5. Senna, A. M. 2014. Analisis Potensi Pariwisata dalam Pelaksanaan Otonomi Daerah di Kota Palopo. Skripsi. Jurusan IImu Politik and IImu Pemerintahan Fakultas IImu Sosial and IImu Politik Universitas Hasanuddin, Makassar. 